\title{
THE SPLEEN IN RENAISSANCE ANATOMY
}

\author{
by
}

\section{ANDREW WEAR*}

\section{SUMMARY AND INTRODUCTION}

IN THIS PAPER I shall be describing the ideas of anatomists on the function and structure of the spleen from the beginning of the sixteenth century until the time of Veslingius in the middle of the seventeenth. The debates on the spleen had no happy outcome in the form of a successful or correct theory as was the case with the sixteenth- and early seventeenth-century arguments on the vascular system. A case-study of the writings by renaissance writers on the spleen does not have the terminus ad quem of a successful theory to colour the interpretation of events. This allows the attitudes and practices of the anatomical writers to emerge more clearly. Therefore, this study of the spleen not only describes what happened to ideas on the function and structure of the spleen during the renaissance but it also attempts to throw light on the interplay between traditional authority, reason and experience in the work of the anatomists. The larger question at issue here is that of the originality of renaissance anatomists with regard to physiology. A detailed case-study is not enough to answer the question, but it can give us a deeper insight into the problem.

What is striking from a present-day point of view is the contrast between the critical scrutiny of authority advanced by the anatomists of the sixteenth century and their practice as exemplified in the case of the spleen and melancholy. Despite the claims to originality, very few new ideas were brought forward in relation to the spleen's function. The alternatives to Galen's account mostly had their origin in Aristotle and in the pseudo-Galenic treatise De utilitate respirationis which embellished Aristotle's idea that the spleen was a bastard liver making poor-quality blood.

\section{THE ANCIENT BACKGROUND}

The principal ancient sources for renaissance discussions on the spleen were Aristotle and Galen supplemented by the Hippocratic corpus, Plato and the writer of De utilitate respirationis. I shall not describe how these writers developed a coherent physiological theory of the function of the spleen, instead I shall concentrate more on those aspects of the ancient writings that influenced the renaissance.

The Hippocratic Corpus was not, on the whole, concerned with the production of an integrated theoretical account of how the human body normally functioned. With the exception of such works as On the nature of man, the emphasis of the Corpus

\footnotetext{
*Andrew Wear, Ph.D., Department of History and Philosophy of Science, King's College, Aberdeen AB9 2UB.

The greater part of this article is based on my doctoral research whilst at Imperial College, London. I would like to thank my supervisor Dr. M. B. Hall for her help and interest in my work and the Wellcome Trust for a Research Studentship that financed my research.
} 


\section{Andrew Wear}

lies on the pathological states of the body as illustrated by case histories and on specific practical procedures to be applied for the cure of particular conditions. This means that there are many reports of the appearance of black bile ${ }^{1}$ but no real account of how it occurs in the body. Although black bile was thought of as a pathological agent responsible for various illnesses, no organ clearly emerges in the Hippocratic writings as responsible for purging the body of black bile. In Galen's work the spleen was thought of as that organ. However, in the Hippocratic corpus the function of the spleen was to draw water from the body ${ }^{2}$ and to prevent the occurrence of illness caused by an excess of water. A possible connexion between the Hippocratic and Galenic doctrines may lie in the fact that in the later Hippocratic works water ${ }^{3}$ was replaced by black bile as a humour with the implication that the spleen should attract black bile ${ }^{4}$ rather than water.

In the Timaeus Plato is more specific concerning the action of the spleen, writing that it serves to cleanse the liver in particular, as well as the body in general, of impurities; but what the impurities are is not specified. ${ }^{5}$ Plato also distinguished between different types of bile and gave them correspondingly different actions. ${ }^{6}$

Aristotle did not follow the Hippocratic and Platonic view of the spleen as a collector of material. In the Parts of animals Aristotle described the spleen as a counterfeit or bastard liver. ${ }^{7}$ This was taken by most sixteenth-century anatomists to mean that the spleen made blood in much the same way as Galen had taught them that the liver produced blood. The difference between venous and splenetic blood was supposed to be that the former was finer in quality as it originated from the right-sided or nobler organ. However, some vestige of the Hippocratic and Platonic teaching can be found in Aristotle, for in a later passage he asserted that "... the spleen attracts the residual humours from the stomach, and owing to its [the spleen's] bloodlike character is enabled to assist in their concoction. Should, however, this residual fluid be too abundant, or that the heat of the spleen be too scanty, the body becomes sickly with over-repletion with nutriment." 8 Although the renaissance anatomists overlooked it, it is probable that Aristotle saw the spleen as a cleansing organ of the body as well as helping in haematopoiesis.

The orthodox account of the spleen in the sixteenth century was based on Galen and it was $\mathrm{Galen}$ who first ${ }^{9}$ linked black bile with the absorbing and cleansing function of the spleen. Galen used pathological evidence to suggest that melanoid skin

${ }^{1}$ See for instance, Hippocrates, Aphorisms, Aphorism 22, Section IV in E. Littré, Oeuvres D' Hippocrates, Paris, J. B. Baillière, 1834-1861, 10 vols., vol. 4, p. 510, where the evacuation of black bile at the beginning of any disease is judged to be a mortal symptom.

De morbis iv, 33, in ibid., vol. 7, p. 544.

3 Water is listed together with phlegm, blood and bile in De morbis, iv, 32, in ibid., p. 542 and also in De semine, chapter 3, in ibid., p. 474.

4 See De natura hominis, chapter 4, in ibid., vol. 6, pp. 38-40.

- Plato, Timaeus 72c, 72d. See the translation of the Timaeus by Benjamin Jowett, The dialogues of Plato, London, Sphere Books, 1970, vol. 3, p. 278.

- Ibid., 83c, p. 289.

'Aristotle, De partibus animalium, Book III, chapter 7 (669b, 670a). See the translation in The works of Aristotle, edited by J. A. Smith and W. D. Ross, vol. 5, London, Oxford University Press, 1912.

- Ibid., Book III, chapter 7, 670 b 5.

- The writings of the Alexandrians are lost, but Galen reports that Erasistratus believed that the spleen was a useless organ. 


\section{The spleen in renaissance anatomy}

characteristics were caused by a malfunction of the spleen in failing to purge the body of black bile. ${ }^{10}$ However, Galen was not only concerned with abnormal states of the body; he was also interested in developing theories to account for the functioning of the healthy body. The evidence from pathology is, therefore, an auxiliary means of showing that the function of the spleen is to attract one of the residues of the liver's concoction of blood from chyle, ${ }^{11}$ and that illness occurs when this does not happen.

Galen ignored the existence of the Hippocratic treatise On the nature of man in which black bile is one of the four humours ${ }^{12}$ and which describes black bile as a natural rather than abnormal constituent of the body. Instead, Galen interpreted the Hippocratic corpus as taking black bile to be a toxic substance. Galen, however, felt the need for a term with more natural and normal connotations, so he replaced the term "black bile" with "black humour". ${ }^{13}$ (Galen was not consistent in his use of "black bile", and "black humour"; I employ the term "melancholy" in the later part of the paper.) There is doubt in Hippocrates of the existence of melancholy as a humour but Galen argued that such a humour must exist. He stated that the four combinations of Aristotelian qualities which constitute the world must also make up the human body. Galen wrote that as the reality of blood, yellow bile and phlegm were agreed on, symmetry demanded a fourth humour.

If then there is a warm and moist humour [blood] and another which is warm and dry [yellow bile], and yet another which is moist and cold [phlegm], is there none which is virtually cold and dry? Is the fourth combination of temperaments which exists in all other things non-existent in the humours alone? No, the black bile is such a humour. This, according to intelligent physicians and philosophers tends to be in excess as regards seasons, mainly in the fall of year, and as regards ages, mainly after the prime of life. And similarly, also they say that there are cold and dry modes of life, regions, constitutions and diseases. Nature, they suppose, is not defective in this single combination; like the three other combinations it extends everywhere. ${ }^{14}$

By using an argument which is based on the identity between the constitution of the macrocosm of the world and that of the microcosm of man Galen indicates that he is not concerned with the abnormal (and particular) but with the normal (and universal). We may note, incidentally, that Galen's argument only holds for a cold and dry humour given the universal applicability of the doctrine of qualities. Galen's identification of black bile as this cold and dry humour is not based, in the present context, on any empirical grounds. It is an apparently arbitrary assertion. What was of concern, however, to most renaissance anatomists was not Galen's logic but his physiological and anatomical account of the spleen's function in relation to melancholy.

Galen placed the function of the spleen in attracting and eliminating melancholy squarely within his general system of digestion. Every part of the body had its proper

\footnotetext{
${ }^{10}$ Galen, On the natural faculties, Book II, chapter IX (133), translated by A. J. Brock, London William Heinemann, and Cambridge, Mass., Harvard University Press, 1916, pp. 204-207.

${ }^{11}$ Chyle was the juice produced from the stomach's digestion of food; it travelled to the liver where it was altered to blood. The two residues of the concoction of blood from chyle were yellow bile and black bile, they were attracted to the gall-bladder and the spleen respectively.

12 See note 4 above.

18 Galen, op. cit., note 10 above. Book II, chapter IX (136), pp. 210-211.

14 Ibid., Book II, chapter IX $(130,131)$, pp. 202-203.
} 


\section{Andrew Wear}

food which it attracted and then assimilated to its own substance, the useless residue being expelled. As part of this process of digestion the liver attracted chyle through the mesenteric veins and then changed the chyle to its own nature-that of congealed blood-in sufficient quantity to satisfy its own needs and those of other parts of the body. ${ }^{15}$ The residues of the elaboration of chyle into blood were yellow-bile and melancholy. Yellow-bile was the proper food of the gall-bladder whilst the thicker and earthier melancholy was the specific food of the spleen ${ }^{16}$ by which it was attracted from the portal vein via "a venous vessel [v. lienalis]". ${ }^{17}$ Melancholy was then concocted by the spleen into a suitable nutriment for itself. As the flesh of the spleen was porous and "very properly nourished by thinner blood" [than the liver], ${ }^{18}$ it meant that the alteration of "the thick, earthy, atrabilious (melancholic) humours"19 into thin blood was a large-scale process. The change from melancholy into the proper food for the spleen was achieved by "the many large arteries ... [ [which] by means of their incessant motion and strength of the innate heat flowing to them from the heart the thick humours conveyed from the liver to the spleen may be elaborated, broken up, altered and transformed." ${ }^{20}$ Galen was concerned with showing how the spleen could change the thick melancholic humour into a substance suitable for its nutrition; he did not conceive that the spleen could produce fine (i.e. arterial) blood for the rest of the body. However, it is possible that this section of De usu partium could have given to renaissance anatomists the idea that the spleen made blood, without their having recourse to Aristotle.

What was left of the melancholic humour and could not be used was carried by a "venous canal"21 into the stomach. Galen wrote that "we shall find the black bile [melancholy] wholly innocuous and even beneficial to the action of the stomach, for it tightens and draws together the stomach and compels it to clasp the food closely and retain it until it is completely concocted. This is the foresight with which Nature has arranged the discharge of the bilious residues."22 (By the time of the sixteenth century an additional function was given to the residue of melancholy in the stomach-that of exciting the appetite.) $)^{23}$

The fact that even the left-overs of melancholy have a function in helping this normal physiological process, the perfect digestion of food, to take place tells us that Galen was totally committed to placing his account of the spleen and melancholy

15 M. T. May (editor), Galen On the usefulness of the parts of the body, Ithaca, Cornell University Press, vol. 1, pp. 221-223.

16 Galen, op. cit., note 10 above, Book II, chapter IX (135-138), pp. 208-213.

17 May, op. cit., note 15 above, p. 206.

18 Ibid., p. 234.

10 Ibid., p. 232.

20 Ibid., pp. 232-233.

21 Ibid., p. 233.

22 Ibid., p. 255.

20 The Arab writers seem to have been responsible for this. The origin of the idea was not usually s pecified during the renaissance but G. Bertinus, Medicina ... . methodice absoluta . . ., Basle, C. Valdkirchius, 1587, p.92, wrote "Meatus vero lienis contra Avicennae opinionem in fundum ventriculi, non in superius orificium, nec ad excitandam famem naturalem sed ad continendos exquisitius cibo, derivatur." See, Avicenna, Avicennae Arabum medicorum principis canon medicinae ... ., Venice, Juntae, 1595, Liber tertius, Fen 13, Tract I, cap 17, p. 698, and Liber tertius, Fen 15, Tract I, cap 2, p. 792. 


\section{The spleen in renaissance anatomy}

within his general description of Nature's workmanship in constructing the body. To this extent Galen went far beyond the Hippocratic account which neither related the spleen and melancholy to each other nor accounted for the normal production and elimination of melancholy.

The last writer to exercise an appreciable influence on renaissance anatomists was the author of the pseudo-Galenic work De utilitate respirationis. ${ }^{24}$ The writer of this work agreed with Aristotle that the spleen made blood and he tried to place this conclusion within an anatomical framework. He went on to assert that the blood from the spleen as well as the liver was attracted to the heart. ${ }^{25}$ De utilitate respirationis has little intrinsic interest but it provided renaissance anatomists with an elaboration of the Aristotelian position on the spleen.

\section{THE RENAISSANCE}

Nearly every renaissance anatomist wrote on the function of the spleen. Their comments range from a few sentences to whole pages and it would be tedious to record them exhaustively. I will, instead, indicate the major changes of thought concerning the spleen. I will discuss also the differing attitudes towards questions of function and examine how the criticism of old theories and the creation of new ones was carried out. The reasons for the poverty of theoretical creativity that faces us when we confront the views of the anatomists are lightly touched upon in the last section of the paper.

\section{THB PRE-VESALIAN PERIOD}

From the time of Mondino (c. 1270-1326) up to that of Vesalius (1514-1564) there was very little written on the spleen and melancholy which was not based on Galen. Some space was devoted to the size, texture, colour, vascular insertions and other anatomical characteristics of the spleen, but Mondino's brevity and indebtedness to Galen, which is matched by that of early sixteenth-century comments on the function of the spleen, is apparent when we read that: "... by the heat of the arteries the crude blood which is to nourish the spleen may be refined and digested, because the spleen hath a fine substance into which it must receive the crude melancholic humour."26

Berengario da Carpi's work is one of the first examples in the sixteenth century of

2 The editors of the third Junta edition listed this work under 'Spurii Libri', It is written with a clear Aristotelian bias, the writer asserted the primacy of the heart over the brain. H. Diels, 'Die Handscriften der antiken Ärzte I Teil', Abh. K. preuss. Akad. Wiss. Philosophisch-historische Classe, 1905, Abh. III, p. 137, refers to the work under its alternative title of De Iuvamento Anhelitus. From Diels it is clear that the work was available in Europe in the thirteenth and fourteenth centuries.

25 Galeno attributus liber de utilitate respirationis, in Galen, Opera omnia latine in septem classes digesta. Ex Juntarum tertia editione, Venice, Heirs of L. A. Junta, 1556, p. 64. As the passage seems to have exercised considerable influence in the renaissance it is worth quoting.

"Dico etiam quod quemadmodum hepar, ita quoque et splen attrahit succum cibi ab intestinis per medium mesenterium cui continuata est vena splenis, quemadmodum et hepatis vena. Unde splen, ut ait Aristoteles recte hepar sinistrum potest appellari. Item a corde protenditur vena ad splenem, quemadmodum, ad hepar, per quam cor attrahit sibi succum cibi a splene, quemadmodum ab hepate."

26 Mondino, Anathomia, translated by Charles Singer, The Fasciculo di medicina, Venice 1493, 2 vols., Venice, Lier, 1925, vol. 2, p. 70. 


\section{Andrew Wear}

a critical approach to the authority of the ancients. However, in his introduction to anatomy, the Isagogae breves of 1522 , there is little hint that the function of the spleen might represent a problem area. The only point of interest in $\mathrm{Da}$ Carpi's essentially Galenic account of the spleen is his statement that the spleen sometimes makes blood: "Some of these [veins] nourish the left part of the stomach and one of them milks the black bile in the stomach's mouth .... Its [the spleen's] complexion is set down as warm and humid, but on account of its content it is regarded as opposite [i.e. cold and dry]. . . . From time to time it makes blood, stirs the appetite, aids the digestion of the stomach . ..". ${ }^{27}$ Clearly Da Carpi considered that the spleen contained melancholy, for the qualities of that humour were cold and dry. Yet $\mathrm{Da}$ Carpi also wrote that the spleen could make blood. From the context it is impossible to tell if $\mathrm{Da}$ Carpi was alluding to the Aristotelian view that the spleen made blood for the rest of the body.

Da Carpi's more discursive work, his commentary on Mondino, the Commentaria published a year before the Isagogae breves in 1521 , provides the answer ${ }^{28} \mathrm{Da}$ Carpi wrote at length on the various opinions that were current concerning the function of the spleen. He explicitly mentioned the Aristotelian position expressed in De utilitate respirationis that the spleen makes blood in the same way as the liver. ${ }^{20}$ However, Da Carpi dismissed this view. He went on to write that the spleen could make blood but only in the limited sense of changing the gross melancholic humour into blood suitable for its nutrition. ${ }^{30}$ Thus, although the Aristotelian alternative was about at the beginning of the sixteenth century, $\mathrm{Da}$ Carpi did not envisage the spleen making blood for the whole body but confined himself to the Galenic description of how melancholy became suitable nourishment for the spleen.

Despite $\mathrm{Da}$ Carpi's lengthy discussion of the function of the spleen in his commentary on Mondino, it is clear that in the Isagogae breves his main concern lay much more with helping the reader to locate the position of the spleen in relation to the stomach and pointing out its form and vascular connexions. The question of the function of the spleen was secondary in Da Carpi's mind. This attitude is found in the work of certain anatomists right through to the middle of the seventeenth century, but it is especially marked up to and including the time of Vesalius.

The emphasis on observational and morphological aspects of the spleen and its surroundings is perhaps best exemplified in the work of Nicholas Massa (1485-1569). In the Preface of his Liber introductorius anatomiae (1536) Massa extolled the virtues of direct sensory and manual experience of anatomy as opposed to mere discourse. ${ }^{31}$ It is this attitude which informs his chapter on the spleen. The function of the spleen was not mentioned. The chapter was devoted to relating the site, substance, colour,

${ }^{27}$ Berengario da Carpi, Isagogae breues, translated by L. R. Lind, Jacopo Berengario da Carpi A short introduction to anatomy, Chicago, University of Chicago Press, 1959, p. 59.

${ }^{28}$ I am grateful to Dr. R. K. French of Cambridge University for bringing Da Carpi's Commentaria to my attention.

so Da Carpi refers to De utilitate respirationis by its alternative title of De iuvamento anhelitus, and takes its author to be Galen; though he adds that Galen was here writing according to the authority of Aristotle; Da Carpi, Carpi commentaria . . . Bologna, H. de Benedictis, 1521, p. 136v.

20 Ibid., pp. 136v.-137r.

:1 Nicolaus Massa, Anatomiae liber introductorius, Venice, J. Zilletus, 1559 (2nd edition), pp. $3 v .-4 r$. 


\section{The spleen in renaissance anatomy}

size, form and vascular connexions of the spleen. ${ }^{\mathbf{3 2}}$ This enumeration of morphological characteristics is found in the work of later anatomists and normally it formed the opening part of any discussion on the spleen. Some of Massa's descriptive termsfor instance the substance of the spleen was "soft, rare, and sponge-like"3s were derived from Galen and were repeated with hardly any modification by successive generations of anatomists. ${ }^{34}$ In other words, particular aspects of the spleen's morphology such as its colour and the texture of its substance were generally agreed upon, and in true text-book tradition were passed on, unchanged, from one author to another.

This emphasis upon the structure as opposed to the function of the spleen is corrected, if not reversed, in the work of Vesalius. Although, as will be seen, not all of Vesalius' contemporaries followed his example.

\section{VESALIUS AND HIS CONTEMPORARIES}

In relation to the spleen at least, Andreas Vesalius produced a quite different level of scientific discourse from any other sixteenth- or early seventeenth-century anatomist. By reference to some of the themes of this paper we could say that Vesalius in the De humani corporis fabrica of 1543 retained and increased the critical concern with morphology that we found in Massa but at the same time he also considered what Massa tended to ignore, that is questions of physiology. However, if Vesalius went beyond Massa, he did not develop the style and attitude of late sixteenth-century academic anatomy, which $I$ discuss below - that is, he did not cite all the ancient and modern opinions on a physiological question and then produce a "solution". A principle of what one might call critical doubt seems to be used by Vesalius when considering the question of the spleen's function. Vesalius subjected established theory to observational criticism where this was possible, and if the theory was called in doubt he did not present an alternative view which would have eradicated the doubt-he was content to leave the question open.

The chapter on the spleen is divided into two parts, an account of the structure of the spleen and an examination of its function. The separation between structure and function is more apparent than real. There is a constant interplay between the two, with the emphasis lying on the examination of function in the light of structural and morphological details.

In an opening dig at his fellow doctors, Vesalius served notice that his account of the spleen was not going to be merely orthodox. He wrote that the position of the spleen was not, as was "thought by the riot of doctors", extended beyond the ribs but that it was enclosed by the ribs as if "by a very safe rampart". ${ }^{35}$

After describing the colour of the spleen in man, Vesalius suggested that the spleen

22 Ibid., pp. 26r.-27v.

23 Ibid., p. 26r.

"Galen wrote that the spleen was "extremely loose-textured and porous like a sponge" (May, op. cit. note 15 above, p. 233). Caspar Bauhin in 1590 wrote that the substance of the spleen was "rara, porosa et spongiosa", (C. Bauhin, De corporis humani fabrica: libri IIII, Basle, S. Henricpetri, 1590 , p. 108).

${ }^{26}$ Andreas Vesalius, De humani corporis fabrica, Basle, J. Oporinus, 1543, p. 511.

"Non enim is, ut medicorum turba arbitratur, sanis alioquin hominibus extra costas, quasi ad abdominis medium anterioraque, non adamussim costis, ceu tutissimis vallis septus, prominet ...". 


\section{Andrew Wear}

should be boiled or placed in warm water to enable it to be handled and inspected more easily because "I was violently in doubt concerning its [the spleen's] use". ${ }^{86}$ This doubt permeates the whole chapter.

The Aristotelian idea that the spleen was a blood-making organ was questioned indirectly, at first, by Vesalius. When considering the vascular nature of the spleen Vesalius wrote that the arrangement of the veins and arteries in the spleen was very different from that in the liver, lungs and kidneys. Moreover, the vessels entering the spleen were not diffused into countless branches as in the liver and lungs but once in the spleen they appeared very thin, and as they did not seem hollow to Vesalius he called them fibres rather than vessels. ${ }^{37}$ One of the working principles of sixteenthcentury anatomy was that if two organs shared a common substance, they should possess a similar function. By indicating that the spleen was unlike the liver, Vesalius was making it harder to identify the spleen's function with the haematopoiec one of the liver.

In the section on the function of the spleen Vesalius explicitly denied that it could make blood. He reported the view of Aristotle that the spleen was a counterfeit liver and then wrote:

In the same way the author of the book 'On the Use of Respiration' which they wrongly attribute to Galen, claims, besides other trash-for example concerning the veins which he testifies are inserted in the gibbosity of the spleen - that the spleen receives the perfected juice [chyle] from the stomach and intestines through the veins of the stomach and intestines, and, in fact, asserts that [it is] an organ of sanguinification. Some of the medical doctors also subscribe to this opinion, declaring that the spleen makes blood on behalf of the liver when the liver has been badly weakened. ${ }^{38}$

Aristotle had not gone into anatomical detail when writing that the spleen was a counterfeit liver. The writer of De utilitate respirationis took Aristotle's idea and had tried to make it anatomically plausible. Vesalius was thus able on observational grounds to attack the general idea of the spleen as a blood-making organ. What Vesalius could not see were the mesenteric veins which were supposed to contain chyle entering the spleen and supplying it with the material to transform into blooda point echoed by Veslingius about a hundred years later. However, Vesalius' report of the view that the spleen could take over from a diseased liver was not accompanied by critical comment. It appears to be inserted as an intermediate opinion. Later Vesalius himself accepted it.

Vesalius emphasized his need to confirm by observation the anatomical structures

36 Ibid., p. 512.

"Necque inutiliter hominis viscera in acqua nonnumquam elixantur aut saltem ut magis concrescat sanguis, in calidam submergentur. Solet enim fluxilis adhuc sanguis in iecore, et liene, et pulmonibus etiam quo minus apte spectari singula queant, impedimento esse. Potissimum autem in liene tentandum hoc duxi quod de ipsius usu vehementer ambigerem" [my italics].

${ }^{37}$ Ibid., p. 512.

38 Ibid., p. 513.

“... Aristoteles lienem adulterati iecoris loco recenset. Eodem modo autor libri de Respirationis usu, quem Galeno falso tribuunt, praeter alia quaedam de venis, quae gibbo lienis inseri arbitratur, nugamenta, lienem ex ventriculo et intestinis confectum cremorem per venas ventriculi et intestinorum assumere, ac sanguificationis organum esse contendit. Huius sententiae nonnulli etiam medicorum subscribunt, lienem iecore male affecto nominem iecoris sanguinem elaborare affirmantes." 


\section{The spleen in renaissance anatomy}

and vascular connexions posited by a particular functional theory when he discussed the Galenic account of the spleen. A particular problem which troubled Vesalius was what happened to that part of the melancholic humour that could not be used as nutriment by the spleen. He wrote that, although everyone agreed that the residue of the melancholic humour was disgorged into the stomach, the way by which the material was transmitted was subject to debate: "some [supposing it is done] by a vein reaching from the spleen into the stomach, others by a certain peculiar passage and then [all agree] it goes from the stomach to the intestine and thence is purged from the body with the faeces". ${ }^{39}$

Vesalius did not see any such passage or vein, and, when he considered the views of those who thought that melancholy excited the appetite as well as helping digestion, he was able to criticize them on observational grounds. Vesalius gave vent to his irony and criticism because they gave a specific location of the points of insertion of the vein from spleen to stomach:

Others, however, not agreeing with this use, however important, add to those uses aforesaid that the appetitive faculty of the stomach is so excited by this excrement that they suppose a vein or channel from the spleen to be inserted into the upper mouth of the stomach chiefly for the sake of this [appetitive] function, thus taught not by dissection but by fancy. I, of course, dare affirm nothing concerning this eructation of the residue of the spleen into the stomach and of its use. Nor, also, does dissection clearly reveal to me that which professors of anatomy assert boldly and categorically. ${ }^{40}$

Here Vesalius has stated that, for the sake of a preconceived idea of the function of the spleen, a communicating vessel between spleen and stomach had been imagined. We should note that Vesalius limited his criticism to cases where arguments from observation could be applied.

The willingness to subject not just structural but also functional statements to observational criticism distinguishes Vesalius from his predecessors. On the other hand, his evident hesitation in producing modified or new physiological theories separates him from the anatomists who follow him.

Ironically, the specific example in his chapter on the spleen that Vesalius used to display his approach to the testing of a functional theory did not turn out to have been well chosen. A vein (the vas breve, one of the short gastric vessels) was seen by Charles Estienne to link the spleen and the stomach. Estienne described the vas breve in the De dissectione partium corporis, ${ }^{41}$ published in 1545 but probably written before

solbid., p. 513.

"Primum enim omnes affirmant, succum melancholicum a liene ventriculum eructari, alii quidem per venam a liene in ventriculum pertinentem, alii per proprium quendam meatum, atque inde a ventriculo in intestina, et hinc una cum faecibus e corpore expurgari."

${ }^{\infty}$ Ibid., p. 513.

"Alii autem huic tantum usui non acquiescentes, iam dictis utilitatibus addunt, vim ventriculi appetitricem hoc excremento adeo incitari, ut eius praecipue usus gratia venam aut porum a liene in superius ventriculi orificium inseri statuant: imaginatione solum, non sectionibus ita edocti. Ego, sane de hoc recrementi lienis in ventriculum eructione, et eius usu nihil affirmare audeo: neque etiam sectio ista luculenter quae tamen citra ullam controversiam Anatomes professores audacissime asserunt, mihi commonstrat." I am indebted to C. D. O'Malley, Andreas Vesalius of Brussels 1514 1564, Berkeley and Los Angeles, University of California Press, 1964, p. 173, for the translation from "sectio ista luculenterr." to the end of the passage.

¿1 Charles Estienne, De dissectione partium corporis humani, Paris, S. Colinaeus, 1545. Estienne drew 


\section{Andrew Wear}

the Fabrica. Later, in 1556, the Spanish anatomist Valverde reported how he had demonstrated the link between spleen and stomach. ${ }^{42}$ Vesalius himself, both in the Letter on the China root ${ }^{43}$ (1546) and in the second edition of the Fabrica ${ }^{44}$ (1555) continued to doubt the existence of a connexion between spleen and stomach. Nevertheless, in the case of the spleen, no other sixteenth-century anatomist followed the approach of the Fabrica in which doubt was induced in a general functional idea through the denial of a specific anatomical structure required by that idea. Where such a method of criticism was used later on, it was as a means of destroying an old functional concept whilst on the road to producing a new one.

Until the publication of De liene libellus in 1578 by Franciscus Ulmus there was little interest or controversy surrounding the function of the spleen. On the whole, the Galenic account of the spleen was accepted; both Fernel ${ }^{45}$ and Realdo Colombo ${ }^{46}$ subscribed to it. The Aristotelian alternative was still present, for instance, Jean Tagault in his De chirurgica institutione (1544) briefly mentioned it when discussing wounds of the spleen. ${ }^{47}$ Vesalius himself seems to have moved some way towards the Aristotelian position.

In the Letter on the China root Vesalius described two cases of men who had lived a number of years with livers that were found on dissection to have been diseased. Faced with the problem of explaining how these men had lived whilst their livers appeared incapable of making blood, Vesalius adopted the compromise position that he had reported in the Fabrica, as being held by some doctors-that is that when the liver was malfunctioning (i.e. small in size) the spleen took over. ${ }^{48}$ However in the Examen (1564), which was Vesalius' reply to the criticisms of the Observationes anatomicae (1561) of Fallopius, Vesalius was far more tentative: "As for the function of the spleen (unless it too is suited for making blood) I have up to now entertained various opinions; but there is no need to write of this, since you have not dignified it with an opinion." 49

the connecting vein between spleen and stomach in the anatomical figure on page 180 of his book, he gave an explanation of the figure on page 181 and he mentions the connecting vein again in his chapter on the spleen on page 185.

12 Valverde De Hamusco, Historia de la composicion del cuerpo humano, Rome, Salamanca and Lafreri, 1556. I have used Michael Colombo's Latin translation, Anatome corporis humani . . . nunc primum a Michaele Columbo Latine reddita, Venice, Juntae, 1589, pp. 266-267.

2 Andreas Vesalius, Epistola, rationem modumque propinandi radicis chynae decocti . . . , Basle, J. Oporinus, 1546, pp. 136-137.

4 Andreas Vesalius, De humani corporis fabrica, Basle, J. Oporinus, 1555, p. 630.

45 Jean Fernel, De naturali parte medicinae, Venice, [J. Gryphius], 1547,pp. 178r.-178v. Fernel gave a completely Galenic description of the spleen and of how melancholy was changed into a suitable nutriment for the spleen. He wrote (p. 178v.) that the spleen ". . . by means of hard labour and the utmost management elaborates it [melancholy], breaks it down, wears it away until it changes it into a sort of thin juice, applying for this action both the strength of its innate heat and the perpetual pulsation of the arteries, which in that place are many and large."

${ }^{46}$ Realdo Colombo, De re anatomica, Venice, N. Bevilacqua, 1559. See the chapter on the spleen pp. 230-231, where Colombo describes the use of the spleen: "Lienis utilitas est, ut melancholicus sanguis ab illa attraheretur, cum praesertim eodem alendus esset."

${ }^{47}$ Jean Tagault, De chirurgica institutione, Venice, Valgrisius, 1549, Book 2, chapter 3, p. 215. Tagault wrote: "Wounds of the spleen are dangerous, since it [the spleen] is especially useful and nearly indispensible and has a duty for the whole body, and is (as some have said) like another liver."

48 Vesalius, op. cit., note 43 above, pp. 173-176.

- Andreas Vesalius, Anatomicarum Gabrielis Falloppii observationum examen, Venice, Franciscus de 


\section{The spleen in renaissance anatomy}

A common characteristic of accounts of the spleen, both of the Galenic and Aristotelian variety, is their short-windedness. No attempt was made to develop arguments to support one particular idea of the spleen's function or another. Vesalius in his critical comments on parts of the orthodox Galenic theory did go to some length, but in the Letter on the China root and in the Examen he merely made an assertion of the spleen's function. Valverde, ${ }^{50}$ Colombo, Tagault and later Coiter ${ }^{51}$ were equally brief. This is partly explained by the fact that no writer had yet highlighted the problem of the spleen. More generally, the lack of reasoning and argument in support of a theoretical statement may be explained as due to a lack of development by anatomists of the conventions of what were acceptable arguments. Academic anatomy, ${ }^{52}$ which grew around the same time as Ulmus published his work on the spleen, rectified the situation and supported the solutions of physiological problems by reason and authority. The conjunction in time of the De liene libellus of Ulmus and the general expansion of academic anatomy with its interest in physiology makes it difficult to decide which of the two was more responsible for the increase in discussion on the function of the spleen.

\section{THE EXPLORATION OF FUNCTION 1578-1641}

The De liene libellus (1578), a highly influential book by a very obscure physician ${ }^{53}$ from Poitiers, brought debate about the spleen to a head. Unlike the writings on the spleen that have been considered so far, the De liene libellus by Franciscus Ulmus is a short monograph on the spleen rather than a passing chapter in a general anatomy book. Another reason for its impact is the startling modification produced by Ulmus in the Aristotelian idea of the function of the spleen.

Ulmus agreed with Aristotle that the spleen made blood, but this was not poorquality venous blood which was added to that produced by the liver. Instead, Ulmus turned his attention to the arterial system.

Up to the time of Harvey the origin of venous blood generally was thought to be the liver, whilst arterial blood was believed to be prepared out of a mixture of venous blood and vital spirits in the left ventricle of the heart. Ulmus decided that the use of the spleen was for "the precoction or preparation of arterial blood", writing: "... it has been known that there is a two-fold substance in the arteries, of which one is from air which retains the name 'spirit' since it flees from the gaze of the eyes, being

Franciscis, 1564. I have used the 1609 edition (Hanau, C. Marnius and heirs of J. Aubrius), p. 191. "Qui vero de lienis usu (nisi is etiam sanguini conficiendo sit accommodus) animum adhuc inconstantem geram, non est quod scribam, quum tu illum observationem non fueris dignatus."

so Valverde, op. cit., note 42 above, p. 187. Valverde, in his chapter on the spleen, devoted one sentence to its function: "The function of the spleen is to purge the blood from the melancholic juice."

s1 Volcher Coiter, Externarum et internarum principalium humani corporis partium tabulae, Nuremberg, T. Gerlatzenus, 1572, p. 24.

"The term "academic anatomy" is taken from R. K. French, Anatomical education in a Scottish university, 1620, Edinburgh, MacInnes \& Whytt, 1974. I have used the Aberdeen, Equipress, 1975 edition, pp. xvi-xix, where Dr. French analyses in a convincing fashion the nature of post-Vesalian anatomy. See also my unpublished London Ph.D. thesis, 1973, 'Contingency and logic in renaissance anatomy and physiology', chapter 8, for a tentative discussion of some of the issues.

"I I have been unable to find any definite information about Ulmus in the standard biographical reference books. In Jöchers there is an entry to Franciscus Olmi who, it is stated, was the uncle of Ulmus. 


\section{Andrew Wear}

understood only by reason. The other [is] from blood, being equally conspicuous in arterial wounds of the living and the dead." 54 The spleen prepared the blood and the lungs prepared the inspired air. The air and blood then travelled to the left ventricle of the heart where they were mixed and given their final coction by the heat of the left ventricle after which they flowed into the body. Ulmus thus changed the status of the spleen. Instead of being a cleansing or auxiliary blood-making organ it now manufactured an essential substance for the body.

This was a radical departure from previous views. The theory did not entail only a change in the function of the spleen, it required major changes in the accepted anatomy and physiology of the blood system. Ulmus asserted that a flow of blood took place upwards from the spleen via the caeliac artery into the trunk of the aorta and thence into the left ventricle of the heart. ${ }^{55}$ Although the systemic circulation had not been conceived, it was commonly agreed that blood flowed outwards from the left ventricle of the heart into the aorta, with the aortic valve preventing any blood entering inwards from the aorta to the left ventricle. The existence of the aortic valve therefore had to be explained away by Ulmus.

Ulmus argued first that a flow of blood upwards from the spleen to the heart was possible. He stated that in the foetus blood flowed into the left ventricle of the heart: "The left ventricle of the heart of the foetus itself attracts the vital and spirituous blood from the maternal uterus through those umbilical arteries." 56 Ulmus then compared the greater need of the adult for vital (arterial) blood with that of the foetus and concluded: "And therefore in the adult, nature ought to make some manifest way through which the blood may lead through into the aortic artery and the left ventricle of the heart, since the need of vital blood is greater in him [the adult] than in the foetus on account of its greater dissipation through the hard labours of the body and the brain." 57

I shall discuss below the way in which Ulmus and other late sixteenth-century anatomists developed supporting arguments for their ideas on the spleen, but at this point we can note why Ulmus was unconvincing to his contemporaries. There is a lack of anatomical clarity when Ulmus gave details of how the blood flowed into the left ventricle of the heart in the adult. He wrote that the "three forked membranes"

\footnotetext{
s4 Franciscus Ulmus, De liene libellus, Paris, M. Patissonius, 1578, p. 13r.: “. . . sanguinis arterialis praecoctionem seu praeparationem appellabo. Duplicem namque in arteriis substantiam esse notum est: quarum una est ex aere quae spiritus nomen retinet, quoniam oculorum obtutum fugit, ratione tantum comprehensa. Altera ex sanguine in viventium pariter atque mortuorum arteriis vulneratis conspicua." Arterial blood according to Galen was derived from venous blood produced in the liver which passed from the right ventricle of the heart via the intraventricular septum into the left ventricle, where it was further elaborated and mixed with vital spirit. Ulmus agreed with Realdo Colombo that the septum was impervious but he denied that the pulmonary route which Colombo had suggested was feasible (p. 18v.-20r.). Ulmus thus substitutes the spleen for the liver as the source for arterial blood.

${ }^{s 5}$ Ibid., p. 19v.

so Ibid., p. 19r.

"Tum enim foetus ipsius cordis ventriculus sinister sanguinem vitalem et spiritum a materno utero alliciebat per arterias illas umbilicales."

${ }^{67}$ Ibid., p. 19r.

"Ergo et in homine grandiore dare debuit natura viam aliquam manifestam, per quam sanguis in arteriam aortam, et sinistrum cordis ventriculum traducatur, cum maior sit in hoc, quam in foetu, sanguinis vitalis necessitas, ob maiorem eiusdem per assiduos corporis et animi labores dissipationem."
} 


\section{The spleen in renaissance anatomy}

(the aortic valve) were not a hindrance:

For they did not, whilst the foetus was in the uterus, prevent the blood with the vital spirit from being enticed from the maternal uterus and transmitted into the great artery through the umbilical arteries of the foetus and introduced into the left ventricle of the heart. Should we not rather say that these little membranes are added, not in order to bar the way into the heart from the artery, but only to reduce the force of the reflux of blood. For otherwise the heat which should be supreme in the left ventricle of the heart might be damped down or even stifled; just as we may see a bright fire damped down and so stifled, sometimes, even in a large and crowded pile of logs.68

When, in 1599, the Galenist Andreas Laurentius wanted to refute Ulmus ${ }^{59}$ he pointed to an unbroken tradition in medicine beginning with Hippocrates which held that the aortic valve was completely impervious to any reflux of blood. Ulmus did not show on observational grounds that the aortic valve was faulty but merely stated that as the left ventricle of the heart was like a fire too much fuel (blood) could swamp it, and so the valve acted as a partial barrier. However, the impermeability of the aortic valve was generally considered a matter for observational anatomy rather than analogical reasoning. Therefore other anatomists could criticize Ulmus on observational grounds.

Ulmus was probably influenced by the Aristotelian belief in the primacy of the heart and more specifically by the work of Argenterius. Ulmus did not go so far as to deny the natural and animal spirits and to assert, as did Argenterius, the sole existence of vital spirit manufactured in the heart. ${ }^{60}$ However, Ulmus did state that the influence of the natural and animal spirits was limited to specific areas whilst the vital spirit acted in all the parts. It may have been partly a desire to elaborate a detailed picture of the generation of vital spirits that led Ulmus to write the De liene libellus and to echo Argenterius' elevation of the heart: "And for this reason you may rightly call it [the heart] with Argenterius, 'the organ of organs' as Aristotle called the hands. For it is, indeed, the vital heat flowing ceaselessly out of the heart which drives and excites each part to its proper work." The De liene libellus can be viewed not only as a stimulus to discussion of the spleen but in a wider sense as being part of a general questioning of the standard Galenic theory of the production and movement of blood.

When one turns back to the traditional (general) anatomy books written after the De liene libellus there are, certainly, many changes. This is not solely due to the ideas

ss Ibid., p. 19v.

"Non etenim prohibebant, dum in utero esset foetus, quominus sanguis cum spiritu vitali ab utero materno prolectus, inde arteriam magnam per umbicales foetus arterias transmissus, in cordis ventriculum sinistrum introiret. An verius dicemus adiectas esse has membranulas, non ut viam ab arteria in cor omnino praecludant: sed ut sanguinis refluentis impetum duntaxat frangant, quo alioquin calor, qui in sinistro cordis, ventriculo excellere debet, obrui vel etiam suffocari posset: non secus ac ignem luculentum videmus obrui, adeoque interdum extigui multa et conferta lignorum congerie?"

${ }^{50}$ Andreas Laurentius, Historia anatomica, Frankfurt, M. Becker for widow and sons of T. de Bry, 1599, p. 248.

${ }^{\circ}$ See Johannes Argenterius, In artem medicinalem Galeni commentarii tres, Mondovi, 'Ex. Off. Torrentiniana', 1566, p. 188.

-1 Ulmus, op. cit., note 54 above, pp. 13r.-13v.

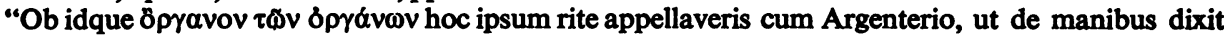
Aristoteles. Is autem est calor vitalis, ex corde perpetuo influens, qui singulas partes ad proprium opus agit et excitat." 


\section{Andrew Wear}

of Ulmus. In the last quarter of the sixteenth century anatomists changed their emphasis away from observation of structures and concern with morphology towards a more philosophical, theoretical and essentially verbalizing approach. The endproduct of this partial movement away from observation has been called academic anatomy. ${ }^{62}$ One of the results of academic anatomy was a concern to write text-books which would, space allowing, include the opinion of ancient and modern authorities on affy question as a necessary prelude to the solution of the problem. Some anatomists produced an opinion which was either a repetition of Galen or Aristotle or a conciliation of the two, whilst others went beyond the ancients and developed their own reasoning to support their view on a particular question.

Archangelus Piccolomini typifies the conciliator of diverse opinions. In his Anatomicae Praelectiones of 1586 he first of all showed his firm belief in the Galenic point of view that: "The spleen, therefore, is to be counted also in the number of those parts which are prepared for the convenience of other parts and of the whole body. For if it did not cleanse the blood of this refuse, like winelees, all the parts of the body would be nourished with impure food and thus would soon succumb to a laborious death from this refuse." ${ }^{63}$ Piccolomini also attempted to integrate the Aristotelian position into his account of the spleen. Vesalius had indicated that where the liver was wasted and malfunctioning then the spleen could take over its blood-making function. He had distinguished this as a separate position from the Aristotelian one which held that the spleen normally acted as a producer of blood. The Vesalian opinion had been related only to specific and limited cases. Piccolomini generalized and incorporated into a scheme of physiology what had originally been a conjectural hypothesis derived from a few pathological cases. The desire to integrate observations or observational inferences into a physiological account of the body is common to most anatomists of the later part of the sixteenth century. Piccolomini thus tried to equate the general Aristotelian view of the spleen with the idea that it could act instead of a diseased liver:

I believe also that the second function of the spleen which Aristotle, as I said a little earlier, seems to have introduced, can be admitted: that is that it is of value and has been provided for the making of the blood. ... If the spleen is endowed with a natural colour and constitution and is much more remarkable and larger than the liver itself, it can be thought that Artistotle's opinion is true, namely, that the spleen has been provided so that it may help the liver making the blood, especially if the liver is much smaller than the spleen, as they say has been found in not a few cases. For that small size of the liver cannot assist all the parts of the body in refining and making blood and thus it was fair for an assistant to be given to it. ${ }^{.4}$

is See note 52 above.

"3 Archangelus Piccolomini, Anatomicae praelectiones . ..., Rome, B. Bonfadinus, 1586, p. 137. "Quare lien habendus quoque est in numero earum partium, quae ad aliarum, et totius corporis, commoditatem comparatae sunt. Nisi enim sanguinem ab hoc crasso, et faecis vinaceae aemulo, excremento repurgaret, partes corporis omnes improbo nutrirentur alimento, atque ita brevi hoc excremento onustae, succumberent internitioni."

as Ibid., p. 137.

"Alterum quoque lienis usum, quem Aristoteles ut paulo ante recitavi, videtur invexisse, admitti posse opinor, scilicet valere datumque esse ad sanguinis confectionem ... Si lien naturali colore et constitutione sit praeditus, isque longe insignior et grandior, quem sit ipsum iecur, existimari potest, Aristotelis mentem, esse veram, nempe lienem datum esse; ut iecori opituletur ad sanguinis confectionem praesertim si iecur longe minus sit liene. Quale in nonnullis compertum esse praedicant. Nam 


\section{The spleen in renaissance anatomy}

For Piccolomini, therefore, the spleen purged the body of melancholy and also produced blood to supplement the liver. The anatomical consequence of such a view was that a two-way flow of melancholy to the stomach from the spleen and of chyle from the stomach to the spleen along the vas breve, was necessary so that the useless part of the melancholic humour could be extruded from the spleen and chyle could be attracted to the spleen to be made into blood. As a justification Piccolomini referred to a similar two-way flow, asserted by Galen, along the mesenteric veins to account for the flow of chyle to the liver and of blood from the liver to the intestines. ${ }^{65}$ Piccolomini not only illustrates the desire to make the ancients agree but he also displays the belief that apparent anatomical problems disappear if a similar apparent absurdity is sanctioned by an established physiological theory. Such an attitude indicates the limited boundaries within which Piccolomini was working, his instinct was to look back and not forward.

Piccolomini's compromise was not taken up, and the beginning of the seventeenth century saw a near-general acceptance of the Aristotelian viewpoint on the spleen. The staunch Galenist Andreas Laurentius held on to the old orthodoxy and gave a strictly Galenic account of the spleen in his well-known text-book the Historia anatomica of 1599. In the 'Anatomical Controversies' appended to his chapter on the spleen, Laurentius' note changed from an urbane confidence in his chosen authority to an anxious acerbity at the impudence of Galen's detractors with question twenty-five of the sixth book of the Historia anatomica entitled, 'De lienis usu contra Galeni calumniatores'.68

Laurentius' anxiety was fully justified. Caspar Bauhin, in an even more popular text-book than that of Laurentius, supported the Aristotelian view of the spleen and most other anatomists followed his particular formulation of the spleen's function. In his earlier work ${ }^{67}$ Bauhin remained neutral on the respective merits of the Galenic and Aristotelian positions but in the Theatrum anatomicum of 1605 he came down in favour of the idea that the spleen made blood.

Bauhin concluded that the spleen attracted the grosser and earthier part of the chyle whilst the liver attracted finer quality chyle and therefore produced better blood. He was thus closer to Aristotle than to Ulmus; the latter had stated that the spleen helped to produce arterial blood which was of a higher degree of elaboration than the liver's venous blood.

Bauhin gave some anatomical details and he explained that the spleen drew the grosser part of the chyle from the trunk of the mesenteric veins by way of the splenic branch of the vena porta before the chyle got to the liver. Bauhin also adduced a semi-anatomical reason in support of his opinion. He wrote that if the spleen did not attract the grosser parts of the chyle then the small vessels of the liver would become obstructed, the liver would cease to perform its function of making blood, and various illnesses such as jaundice, dropsies, fevers and cirrhoses would occur. ${ }^{88}$

parva illa iecoris moles, in sanguine elaborando atque conficiendo, omnibus corporis partibus subvenire nequit, idcirco auxiliarium ei dari, par erat."

es Ibid., p. 137.

es Laurentius, op. cit., note 59 above, p. 248.

" Bauhin, op. cit., note 34 above, p. 55 and pp. 108-110.

8 Caspar Bauhin, Theatrum anatomicum, Frankfurt, M. Becker, 1605, p. 278. 


\section{Andrew Wear}

Now the interesting point is that these illnesses were precisely those that were supposed to occur when a malfunctioning spleen allowed too much melancholy to remain in the body. In other words there is implicit an idea of the "grosser and earthier part of the chyle" being equivalent to melancholy. The effect of the equation of a part of the chyle with melancholy was to ensure that illnesses previously explained by melancholy could still be described in terms of a substance qualitatively the same as melancholy, even though the existence of melancholy might, now, be in doubt as it had lost its role in the physiology of the body as the proper food of the spleen.

Bauhin's theory of the spleen was not completely rounded and several compromises with the past are apparent. Bauhin himself did not completely deny the existence of melancholy. He wrote that melancholy was produced by the liver but instead of going to the spleen it was mixed into the blood in general. ${ }^{69} \mathrm{He}$ also weakly echoed Ulmus, writing that "perhaps" a certain part of the blood produced by the spleen might go into the left ventricle of the heart. ${ }^{70}$ Again, Bauhin drew support at one point in his argument from Vesalius ${ }^{71}$ that the spleen could take over the function of the liver, but this was merely to show that an intermediate position on the way to his own conclusion had been reached by others; for he quoted with greater approval the opinion of Piccolomini who had generalized the limited remarks of Vesalius. ${ }^{72}$ Given this use of Vesalius, it is surprising to find near the conclusion of the chapter that one of the integral functions of the spleen is to perform the liver's blood-making duty when it is diseased. ${ }^{73}$ This lack of coherence may have been caused by the exigencies of producing a standard text-book which included not only Bauhin's own views but those of the various authorities, and in which the ultimate solution to a problem included both types of opinion.

The impact of the Theatrum anatomicum was to alter the Galenic interpretation of the spleen's function. It was done in such a way that what might have appeared as extreme innovation in Ulmus became an acceptable alternative in Bauhin. Undoubtedly, the reason that Bauhin was able to do this was that, unlike Ulmus, he chose to make his position very close to that of Aristotle and to appear to be merely propounding an alternative opinion drawn out of the ancient authorities. This in fact, was what it probably looked like to Bauhin himself; yet his chapter on the spleen contained more innovation than is to be found in any previous writer except Ulmus. Aristotle had not spelled out the consequences and details of his view. This is what Bauhin did in the name of Aristotle and, because it was in that name, Bauhin was followed by later anatomists.

BAUHIN'S SUCCESSORS

Various other writers such as Spigelius ${ }^{74}$ and Caspar Bartholin ${ }^{75}$ developed and

๑ Ibid., p. 277.

${ }^{70}$ Ibid., p. 278.

${ }^{11}$ Ibid., p. 276.

"Isid., p. 276.

78 Ibid., p. 278.

"Adrianus Spigelius, De humani corporis fabrica libri decem opus posthumum, Frankfurt, M. Merian, 1632, pp. 309-313.

${ }^{75}$ Caspar Bartholin, Anatomicae institutiones, [Wittenberg?], A. Rüdinger for B. Raab, 1611, pp. 96-106. 


\section{The spleen in renaissance anatomy}

expanded Bauhin's ideas on the spleen, and Caspar Hofmann ${ }^{76}$ composed a book on the subject. However no real change took place until Veslingius wrote the Syntagma anatomicum (1641). Veslingius had the work of Aselli on the lacteals before him which gave him a better understanding of the mesenteric region from which, according to Bauhin, the spleen would draw chyle. Veslingius wrote that the blood-making faculty of the spleen was agreed to, "according to the largest consensus of opinion". He wrote that the ways, however, in which the material is sent to the spleen were obscure just as if nature closed it in by darkness. Veslingius could not detect lacteal ducts leading to the spleen, nor, he wrote, was anything observed to be brought by the splenic vein or its branches to the spleen, even though he had made abundant vivisections and used ligatures. ${ }^{77}$ In the end Veslingius did not explicitly deny the new doctrine but his doubt is of the same nature as Vesalius'-he could not observe the anatomical conditions required by the functional theory.

\section{CONCLUSION}

The work of post-Vesalian anatomists is redolent with the constricting nature of the theoretical boundaries that enclosed them. The basic physiology of the body had been laid down by the ancients and radical alternatives such as iatrochemistry, chemistry or a mechanistic approach were either not taken up or not available. Thus to tamper with any component of qualitative physiology and humoral pathology meant doing damage to other parts of the system. The way out was for anatomists such as Ulmus and Bauhin to introduce their innovations by implying that the existing system of physiology was not completely coherent and true to the principles upon which it had been built. In other words, if Galen were corrected on a detail of function it was in order that a "true" or "correct" Galen might emerge devoid of contradiction.

The major mechanism for achieving this was the use of the principle of "similar structure-similar function". Ulmus used it when he denied that the spleen attracted melancholy. He argued that as the spleen did not possess a cavity it could not attract melancholy; for all organs that attracted excrements had conspicuous cavities. ${ }^{78} \mathrm{This}$ argument is also found in Bauhin ${ }^{79}$ and Spigelius. ${ }^{80}$ Again, when Ulmus wanted to make the positive assertion that the spleen manufactured blood, he pointed out that the spleen had the same convoluted structure as other organs that manufactured fluids and must therefore share their function. He wrote:

A similar and equal use appears in the lungs, in the testicles and spermatic vessels, the choroid

76 Caspar Hofmann, De usu lienis secundum Aristotelem, [Leipzig], Heirs of $\mathrm{V}$ am Ende for $\mathrm{J}$. Börnerus snr. and E. Rehefeldius, 1615.

"Johannus Veslingius, Syntagma anatomicum. I have used the 1666 edition, Amsterdam, Johannus Jansonius, pp. 68-69. "Actionem lienis, ex majore doctorum consensu, constituto confectionem sanguinis, aquosiore chyli portione, administisque partibus terreis sordida. Quibus autem viis ad officinam illam feratur haec materia, caliginosa veluti nocte natura premit. Nam lacteos ad lienem ductus nulla hactenus observatio detexit. Per venam etiam splenicam, et ab ea productos ramos nihil ad lienem deferri, abunde vivorum animantium dissectio, atque in iis instituta vasorum ligatura patefecit."

78 Ulmus, op. cit., note 54 above, p. 12 r.

70 Bauhin, op. cit., note 68 above, p. 275.

20 Spigelius, op. cit., note 74 above, p. 311. 


\section{Andrew Wear}

plexus, the breasts capable of producing milk, in all [of ]which nature has made a similar plexus of vessels, because they were to concoct new material. ... In short there is no part of the body with these evident intertwinings and bendings of the vessels which does not produce a new work and does not make a new form by itself subduing and overcoming the material. It will not be absurd therefore ... if we judge that the spleen [has been] made by nature so that it predigests arterial blood. ${ }^{.1}$

This type of reasoning can be found in Piccolomini when he argued that if the spleen looks like the liver in colour and magnitude then it will perform the same function as the liver. ${ }^{82}$ In fact, the principle of "similar structure-similar function", recurs in most anatomical writers of the later part of the sixteenth century. Its use points to the limited degree of freedom that the anatomists gave themselves in constructing new physiological theories. For, despite the novelty of a view such as that of Ulmus on the spleen, the scheme within which Ulmus was working was Galen's. The functions of the lungs, breasts, and other plexiform organs with which Ulmus hoped to homologize the spleen had all been set down by Galen.

In the end we are left with the fact that the anatomists from the time of $\mathrm{Da}$ Carpi to that of Bauhin accomplished very little. After nearly a hundred years of endeavour the net result was that the majority of anatomists had come down on the side of Aristotle. The debate about the spleen did not alter in its essential form-that of the choice between the Galenic and Aristotelian alternatives. If observational anatomy had become a self-sufficient science then physiology was foundering in its wake; presenting, in the case of the spleen at least, little sign that it also could be independent -but of course it could not be, nor did it become so.

1 Ulmus, op. cit., note 54 above, p. 22 r.

"Similis parque usus apparet in pulmonibus, testibus, vasisque seminariis, plexu choroede, mamm is lactantium: in quibus omnibus fabricata est natura similem vasorum implexum, quia novam coquere materiam debebant .... Denique nulla est in corpore pars, his vasorum implexibus et anfractibus insignita, quae novum opus non edat, novamque formam materiei a se subactae et edomitae non affingat. Non absurdum igitur fuerit ... si lienem a natura conditum iudicemus, ut sanguinem praecoquat arterialem."

s2 Piccolomini, op. cit., note 63 above, p. 137. 